\title{
Optimization of Prickly Pear Juice Clarification for Better Retention of Betalain and Color Properties
}

\author{
P.R. Davara, A.K. Varshney, V.P. Sangani, P.P. Vora
}

10.18805/ajdfr.DR-1693

\begin{abstract}
Background: Prickly pear juices are considered as valuable ingredient for sports and energy drinks due to its higher amino acids contents, minerals and attractive red color. Hence, prickly pear fruit has received renewed interest for the production of juice. Up to date, relatively little work has been reported regarding the manufacturing of prickly pear products. Enzyme has proved to be the key element for producing clear and stable fruit juice. The present study aimed to optimize the processing parameters for enzymatic clarification of prickly pear juice. The results of this investigation are expected to provide the suitable process technology for the production of prickly pear juice with better retention of betalain content and color value.

Methods: Prickly pear pulp was treated with pectinase enzyme at different concentrations $(0.01-0.09 \%)$, incubation temperatures $\left(40-60^{\circ} \mathrm{C}\right)$ and incubation time $(60-180 \mathrm{~min})$. The effect of enzymatic treatments on clarity, color index, betalain content and ascorbic acid content of juice were studied through response surface methodology by employing second order central composite rotatable design.

Result: Response surface analysis determined the optimum condition for clarifying prickly pear juice as $0.036 \%$ enzyme concentration, $46^{\circ} \mathrm{C}$ incubation temperature and $112 \mathrm{~min}$ incubation time. At this condition, it was predicted to produce the prickly pear juice with clarity of $48.59 \% \mathrm{~T}$, color index of 0.603 abs, betalain content of $542.93 \mathrm{mg} / \mathrm{L}$ of juice and ascorbic acid content of $9.35 \mathrm{mg} / 100 \mathrm{~g}$ with the desirability of 0.780 .
\end{abstract}

Key words: Betalain content, Color, Enzymatic treatment, Juice clarification, Pectinase, Prickly pear.

\section{INTRODUCTION}

Juice production is one of the most frequently utilized process technologies in the fruit processing industry. Juices are much appreciated for their nutritive value and sensory properties (Kgatla et al., 2011). Prickly pear juices are considered as a valuable ingredient for sports and energy drinks due to its higher amino acids contents (Seidl et al., 2000). The pulp has an attractive color that varies from soft green, greenish-white, canary-yellow, orange-yellow, lemonyellow, red and cherry-red to purple hues (Sáenz, C. and Sepúlveda 2001). These attractive colors are due to the betalains comprising the red-violet betacyanins and the yellow-orange betaxanthins (Fernandez- López and LuisAlmela 2001). The other functional benefits such as immunity boost up, bones and teeth building, digestive health maintenance, heart health enhancement, anti-carcinogenic effects, antioxidant potential, weight loss effects and inflammation suppression are also associated with this fruit (Joshi et al., 2020). Due to this color property, prickly pear juice has been considered as valuable source for enhancing the nutritional content and color in fruit juice blends viz., orange-apple juice blends (Moreno- Álvarez et al., 2003). The key of producing clear and stable fruit juice is a complete enzymatic breakdown of pectin (Lee et al., 2006). The treatment of mash with pectinases causes the degradation of cell wall and middle lamella of plant cells. This releases the fruit juice and increases yield (Demir et al., 2001; Saxena et al., 2014). (Enzymatic treatments using pectinase have also assisted in the improvement of yield and reduction of
Department of Processing and Food Engineering, College of Agricultural Engineering and Technology, Junagadh Agricultural University, Junagadh-362 001, Gujarat, India.

Corresponding Author: P.R. Davara, Department of Processing and Food Engineering, College of Agricultural Engineering and Technology, Junagadh Agricultural University, Junagadh-362 001, Gujarat, India. Email: pareshdavara@yahoo.com

How to cite this article: Davara, P.R., Varshney, A.K., Sangani, V.P., Vora, P.P. (2022). Optimization of Prickly Pear Juice Clarification for Better Retention of Betalain and Color Properties DOI: 10.18805/ajdfr.DR-1693.

Submitted: 19-04-2021 Accepted: 16-10-2021 Online: 07-01-2022

turbidity of prickly pear juice (Davara et al., 2017). The fundamental physical property of food products is color. Color of juice is affected by natural enzymes, oxidation of ascorbic acid and the Maillard reaction, which depends on the content of reducing sugars, proteins and temperature (Mackay et al., 1990). The enzymatic hydrolysis of pectic substances depends on several processing variables such as type of enzyme, hydrolysis time, enzyme concentration, incubation temperature and pH (Lee et al., 2006; Sin et al., 2006). These parameters need to be optimized for maximum clarity and color retention of juice. In order to this, optimization studies for prickly pear juice clarification were conducted using response surface methodology (RSM). The aim of the study was to assess the effect of enzymatic process parameters on different quality and color characteristics of clarified 
Optimization of Prickly Pear Juice Clarification for Better Retention of Betalain and Color Properties

prickly pear juice and to optimize the process condition through response surface methodology.

\section{MATERIALS AND METHODS}

The experiment was carried out at Dept. of Processing and Food Engineering, College of Agricultural Engineering and Technology, Junagadh Agricultural University, Junagadh.

\section{Raw materials}

The prickly pear fruits were collected from the plants grown at nearby areas of Junagadh (Gujarat, India). Fully ripe fresh, bright red and purple color fruits, without any visual defects, were selected for the experimental work. Commercial food grade pectinase enzyme was purchased from HiMedia Laboratories Pvt. Ltd., Mumbai (Maharashtra, India) and stored at $4^{\circ} \mathrm{C}$. The activity of pectinase enzyme as reported by the supplier was $8000-12000 \mathrm{U} / \mathrm{g}$.

\section{Enzymatic clarification}

For each experiment, $100 \mathrm{~g}$ pulp was subjected to different enzymatic treatments under different conditions as shown in Table 1. The pectinase enzyme was added to each pulp sample and placed in an incubator for incubation at desired levels of temperature and time. At the end, suspension was heated in a water-bath at $90^{\circ} \mathrm{C}$ for $5 \mathrm{~min}$ to inactivate the enzyme present in the sample (Lee et al., 2006). The enzyme treated prickly pear pulp samples were then centrifuged at $3600 \mathrm{rpm}$ for 10 minutes. The supernatant was collected and then filtered using 2 folds muslin cloth to get the clear prickly pear juice. It was then filled in glass bottles and stored at $7{ }^{\circ} \mathrm{C}$ in refrigerator for further analysis.

\section{Physicochemical analysis}

Clarity was determined by measuring the percent transmittance (\%T) at wavelength of $660 \mathrm{~nm}$ using UV-VIS spectrophotometer (UV 5704SS, Electronics Corporation of India Pvt. Ltd., Hyderabad, India) (Lee et al., 2006). Distilled water was used as reference. The color index was determined as per the method proposed by Meydov et al. (1977). The betalain content of prickly pear juice was quantified as per the method proposed by Nilsson (1970). The betalain content was calculated using an equation proposed by Cai and Corke (1999). Ascorbic acid was determined by the method described by Hans (1992). The ascorbic acid content was calculated as $\mathrm{mg} / 100 \mathrm{~g}$ of edible portion.

\section{Experimental design and statistical analysis}

Response surface methodology has found be very useful and reliable method for optimizing the process parameters in many of the research experiments (Kaur et al., 2018; Prema et al., 2018; Balasubramanian et al., 2020). It was used for designing of the experiment (Khuri and Cornell 1987). The software package Design Expert version 10 was used to generate the experimental designs, statistical analysis and regression models. A three-factor five-level Central Composite Rotatable Design (CCRD) with quadratic model was employed to study the combined effect of three independent variables, viz., enzyme concentration, incubation temperature and incubation time on different response variables. The response function $(\mathrm{Y})$ was related to the coded variables by a second order polynomial equation which can be given as under.

$$
\begin{aligned}
Y= & b_{0}+b_{1} X_{1}+b_{2} X_{2}+b_{3} X_{3}+b_{11} X_{1}^{2}+b_{22} X_{2}^{2}+ \\
& b_{33} X_{3}^{2}+b_{12} X_{1} X_{2}+b_{12} X_{1} X_{2}+b_{12} X_{1} X_{3}+b_{23} X_{2} X_{3}
\end{aligned}
$$

The coefficients of polynomial were represented by $b_{0}$ (constant term), $b_{1}, b_{2}$ and $b_{3}$ (linear effects), $b_{11}, b_{22}$ and $b_{33}$ (quadratic effects) and $b_{12}, b_{13}$ and $b_{23}$ (interaction effects). Analysis of variance (ANOVA) tables were generated and regression coefficients of individual linear, quadratic and interaction terms were determined (Khuri and Cornell 1987).

\section{Optimization and validation of process variables}

The optimization of process variables was carried out using Design Expert software. Optimum values of the selected variables were analyzed by the response surface contour plots and also by solving the regression equation. The optimum condition as obtained through response surface analysis was verified by conducting the experiments in triplicate. The average experimental value of different response variables was used to check the validity and adequacy of the predicted models.

\section{RESULTS AND DISCUSSION}

\section{Effect of enzymatic treatment on clarity of juice}

The effect of enzyme concentration, temperature and time on clarity of prickly pear juice is presented in the Table 1. Fig 1a showed that the clarity of juice was increased with an increase in the enzyme concentration and incubation temperature up to $0.087 \%$ and $43^{\circ} \mathrm{C}$, respectively. It was expected to be increased up to $50.94 \% \mathrm{~T}$ at this combination of enzyme concentration and temperature. The perusal of contour map (Fig 2a) indicated that the clarity of juice was increased with an increase in incubation temperature up to $47^{\circ} \mathrm{C}$ and incubation time up to its maximum level of 180 min. This interaction level of temperature and time was proposed to increase the juice clarity up to $55.04 \% \mathrm{~T}$. The interaction of enzyme concentration and incubation time caused to increase the clarity up to $54.81 \% \mathrm{~T}$ (Fig 3a). The enzyme concentration and incubation time at this juncture was determined as $0.062 \%$ and $180 \mathrm{~min}$, respectively. The higher incubation time provided the sufficient time to pectinase for breakdown of pectin which was the main phenomenon responsible for increase in juice clarity after prolonged time (Karangwa et al., 2010). The resultant model, giving the empirical relation between the clarity of juice and the test variables in coded units, was obtained as under.

Clarity $=49.51+0.285 \mathrm{X}_{1}-10968 \mathrm{X}_{2}+1.983 \mathrm{X}_{3}-0.787 \mathrm{X}_{1}^{2}$ $-1.975 X_{2}^{2}+0.641 X_{3}^{2}-1.806 X_{1} X_{2}+0.271 X_{1} X_{3}+0.111 X_{2} X_{3}(3)$

Effect of enzymatic treatment on color index of juice

The data as tabulated in Table 1 as well as the interaction 
plots of color index of prickly pear juice (Fig 1b) showed the positive effect of enzyme concentration and incubation temperature up to $0.047 \%$ and $44^{\circ} \mathrm{C}$, respectively. This interaction was expected to increase the color index of juice up to 0.612 abs. However, with further increase in enzyme concentration and incubation temperature, the color index was decreased. Similarly, the positive effect of interaction of incubation temperature and time on color index of prickly pear juice was observed up to $44^{\circ} \mathrm{C}$ and $126 \mathrm{~min}$, respectively. It was likely to be increased up to 0.612 abs at this combination of temperature and time (Figure $2 b$ ). Further increase in incubation temperature and time reduced the color index of juice. The interaction of enzyme concentration and incubation time, was effective up to $0.042 \%$ and 131 min, respectively. This interaction was expected to improve the color index of juice up to 0.596 abs (Figure 3b). But, the color index was decreased with further rise in enzyme concentration and incubation time. The regression model as derived for the color index of juice is given as under.

$$
\begin{aligned}
& \text { Color index }=0.593-0.009 X_{1}-0.034 X_{2}+0.008 X_{3} \text { - } \\
& 0.016 X_{1}^{2}-0.016 X_{2}^{2}+0.017 X_{3}^{2}-0.005 X_{1} X_{2} \\
& +0.008 X_{1} X_{3}+0.002 X_{2} X_{3}
\end{aligned}
$$

\section{Effect of enzymatic treatment on betalain content}

The data showing the effect of enzyme concentration, temperature and time on betalain content of clarified prickly pear juice are tabularized in Table 1. The response surface and contour plot for the betalain content of juice as a function of enzyme concentration and incubation temperature (Figure 1c) revealed that betalain content of juice was increased with an increase of enzyme concentration up to $0.05 \%$ and incubation temperature up to $47^{\circ} \mathrm{C}$, respectively. For this interaction, it was possible to increase the betalain content of juice up to $544.80 \mathrm{mg} / \mathrm{L}$. The contour map for betalain content (Fig 2c) indicated that interaction of incubation temperature and time positively affected the betalain content till $47^{\circ} \mathrm{C}$ and $128 \mathrm{~min}$, respectively. The betalain content of the juice was expected to be increased up to $544.90 \mathrm{mg} / \mathrm{L}$ of juice at this combination of temperature and time. The betalain content was found to be decreased with further increase in temperature and time. For the third interaction as shown Fig 3c, the betalain content was found to be increased up to $0.053 \%$ enzyme concentration and $147 \mathrm{~min}$ incubation time. This combination was expected to increase the betalain content up to $542.64 \mathrm{mg} / \mathrm{L}$ of juice. The following empirical model in coded form was derived for the betalain content.

Betalain conttent $=$

$542.635-0.687 X_{1}-8.237 X_{2}+3.532 X_{3}-5.356 X_{1}^{2}-7.836 X_{2}^{2}$ $+2.957 X_{3}^{2}-1.498 X_{1} X_{2}+0.41 X_{1} X_{3}+5.025 X_{2} X_{3}$

\section{Effect of enzymatic treatment on ascorbic acid}

Increase of enzyme concentration and incubation temperature, could play the beneficial role only up to $0.062 \%$

Table 1: Effect of enzyme concentration, incubation temperature and incubation time on response variables of clarified prickly pear juice

\begin{tabular}{lccccccc}
\hline Treatment & \multicolumn{3}{c}{ Independent Variables } & \multicolumn{3}{c}{ Responses. } \\
\cline { 2 - 7 } & $\begin{array}{c}\text { Enzyme Conc. } \\
(\%)\end{array}$ & $\begin{array}{c}\text { Temp. } \\
\left({ }^{\circ} \mathrm{C}\right)\end{array}$ & $\begin{array}{c}\text { Time } \\
(\mathrm{min})\end{array}$ & $\begin{array}{c}\text { Clarity } \\
(\% \mathrm{~T})\end{array}$ & $\begin{array}{c}\text { Color index } \\
(\text { abs })\end{array}$ & $\begin{array}{c}\text { Betalain content } \\
(\mathrm{mg} / \mathrm{L} \text { of juice })\end{array}$ & $\begin{array}{c}\text { Ascorbic acid } \\
(\mathrm{mg} / 100 \mathrm{~g})\end{array}$ \\
\cline { 2 - 7 } & $\mathrm{X}_{1}\left(\mathrm{x}_{1}\right)$ & $\mathrm{X}_{2}\left(\mathrm{x}_{2}\right)$ & $\mathrm{X}_{3}\left(\mathrm{x}_{3}\right)$ & $\mathrm{Y}_{1}$ & $\mathrm{Y}_{2}$ & $\mathrm{Y}_{3}$ & $\mathrm{Y}_{4}$ \\
\hline 1 & $0.026(-1)$ & $44(-1)$ & $84(-1)$ & 46.31 & 0.581 & 538.51 & 9.56 \\
2 & $0.074(1)$ & $44(-1)$ & $84(-1)$ & 50.02 & 0.580 & 537.21 & 9.28 \\
3 & $0.026(-1)$ & $56(1)$ & $84(-1)$ & 45.75 & 0.502 & 508.91 & 9.23 \\
4 & $0.074(1)$ & $56(1)$ & $84(-1)$ & 42.12 & 0.497 & 511.62 & 8.95 \\
5 & $0.026(-1)$ & $44(-1)$ & $156(1)$ & 49.14 & 0.601 & 536.56 & 8.99 \\
6 & $0.074(1)$ & $44(-1)$ & $156(1)$ & 53.82 & 0.585 & 534.92 & 9.32 \\
7 & $0.026(-1)$ & $56(1)$ & $156(1)$ & 48.91 & 0.544 & 525.08 & 8.66 \\
8 & $0.074(1)$ & $56(1)$ & $156(1)$ & 46.48 & 0.494 & 531.41 & 8.85 \\
9 & $0.01(-1.682)$ & $50(0)$ & $120(0)$ & 46.21 & 0.558 & 524.33 & 9.14 \\
10 & $0.09(1.682)$ & $50(0)$ & $120(0)$ & 47.14 & 0.531 & 526.28 & 9.10 \\
11 & $0.05(0)$ & $40(-1.682)$ & $120(0)$ & 46.54 & 0.591 & 530.87 & 9.28 \\
12 & $0.05(0)$ & $60(1.682)$ & $120(0)$ & 40.09 & 0.498 & 505.71 & 8.63 \\
13 & $0.05(0)$ & $50(0)$ & $60(-1.682)$ & 46.87 & 0.528 & 527.18 & 9.23 \\
14 & $0.05(0)$ & $50(0)$ & $180(1.682)$ & 54.56 & 0.555 & 537.00 & 8.71 \\
15 & $0.05(0)$ & $50(0)$ & $120(0)$ & 48.92 & 0.592 & 540.95 & 9.25 \\
16 & $0.05(0)$ & $50(0)$ & $120(0)$ & 49.27 & 0.588 & 544.00 & 9.27 \\
17 & $0.05(0)$ & $50(0)$ & $120(0)$ & 48.70 & 0.600 & 544.67 & 9.24 \\
18 & $0.05(0)$ & $50(0)$ & $120(0)$ & 50.49 & 0.582 & 540.06 & 9.16 \\
20 & $0.05(0)$ & $50(0)$ & $120(0)$ & 49.22 & 0.595 & 543.73 & 9.23 \\
\hline 19 & $0.05(0)$ & $50(0)$ & $120(0)$ & 50.67 & 0.603 & 543.15 & 9.21 \\
\hline
\end{tabular}

Note: value $\mathrm{s}$ in parenthesis are coded value. 


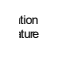
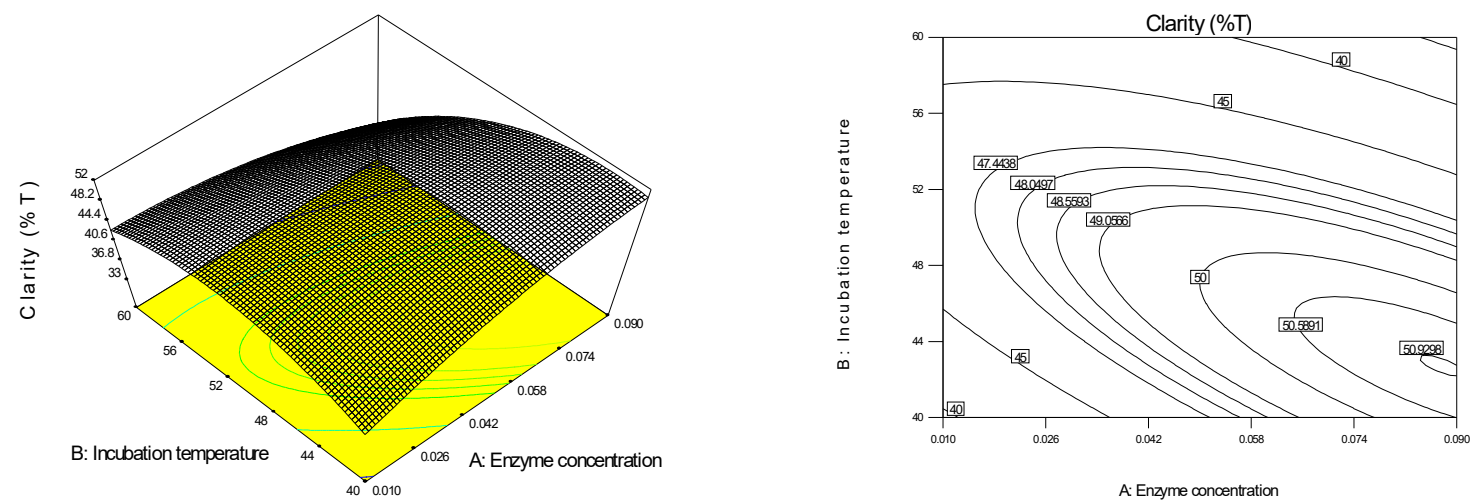

a. Clarity of juice

A: Enzyme concentration
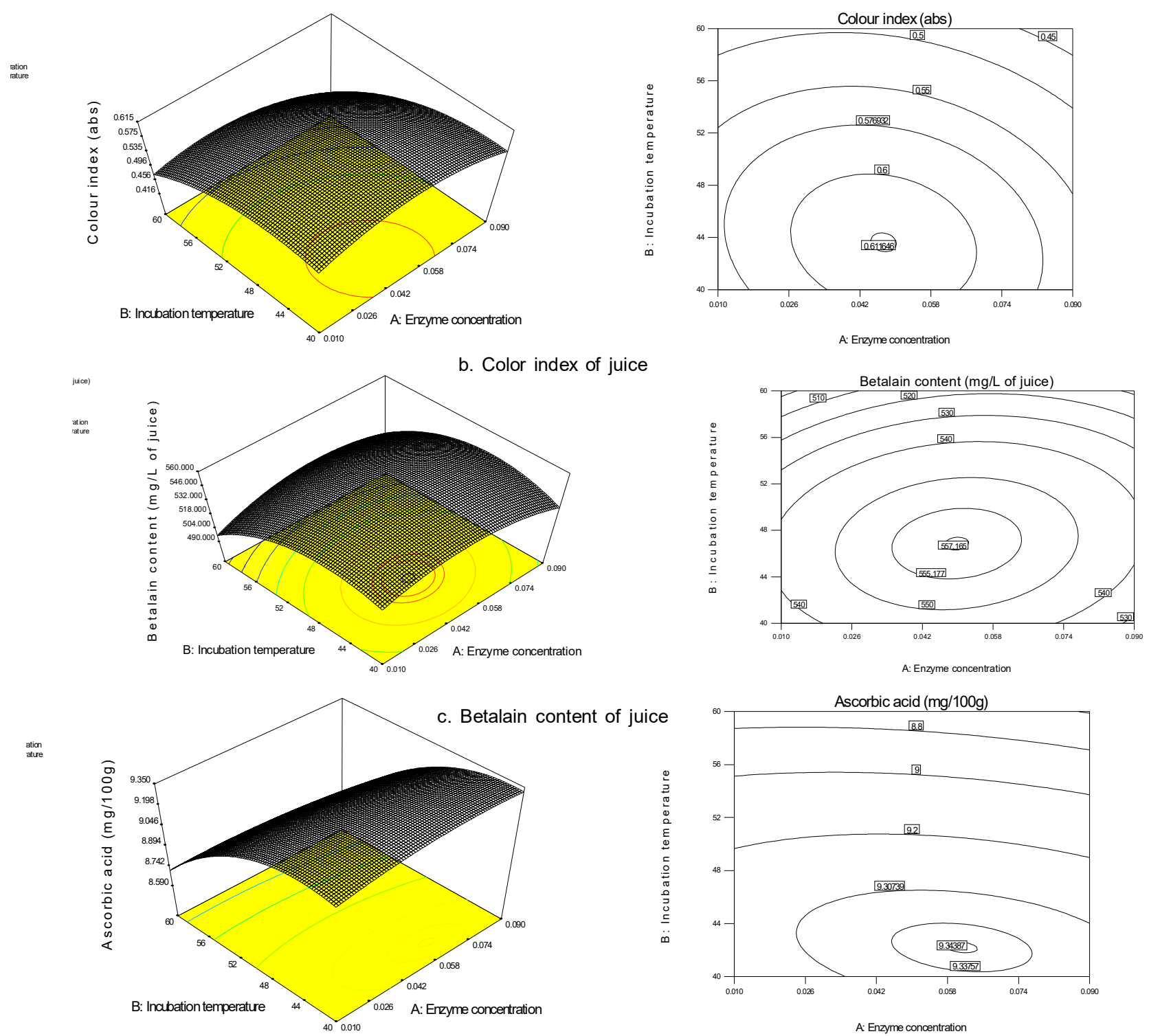

d. Ascorbic acid content of juice

Fig 1: Interaction effect of enzyme concentration and incubation temperature on clarity, color index, betalain content and ascorbic acid (Incubation time was at the centre point, i.e. $120 \mathrm{~min}$ ). 
and $42^{\circ} \mathrm{C}$, respectively and expected to increase the ascorbic acid up to $9.34 \mathrm{mg} / 100 \mathrm{~g}$ (Fig 1d). Increase in ascorbic acid was observed with the increase of incubation temperature and time up to $43^{\circ} \mathrm{C}$ and $86 \mathrm{~min}$, respectively (Fig $2 \mathrm{~d}$ ). This interaction predicted the rise in ascorbic acid up to $9.40 \mathrm{mg} / 100 \mathrm{~g}$. The interaction effect as presented through contour graph (Fig $3 d$ ) revealed that there was decrease in ascorbic acid in the juice with an increase in both enzyme concentration and incubation time. Incubation time had shown its significant effect in decreasing ascorbic acid in comparison to enzyme concentration. Therefore, the lowest ascorbic acid $(8.36 \mathrm{mg} / 100 \mathrm{~g})$ was observed at combination of $0.01 \%$ enzyme concentration and $180 \mathrm{~min}$ incubation time. While, the highest $(9.63 \mathrm{mg} / 100 \mathrm{~g})$ was observed for the interaction of $0.01 \%$ enzyme concentration and $60 \mathrm{~min}$ incubation time. The model as derived and giving the empirical relation between ascorbic acid vale and test variables in coded units, was obtained as under.

$$
\begin{aligned}
& \text { Ascorbic acid }= \\
& 9.223-0.008 \mathrm{X}_{1}-0.187 \mathrm{X}_{2}+0.152 \mathrm{X}_{3}-0.016 \mathrm{X}_{1}^{2}- \\
& 0.074 \mathrm{X}_{2}^{2}+0.069 \mathrm{X}_{3}^{2}-0.018 \mathrm{X}_{1} \mathrm{X}_{2}+0.135 \mathrm{X}_{1} \mathrm{X}_{3}+ \\
& 0.018 \mathrm{X}_{2} \mathrm{X}_{3}
\end{aligned}
$$

\section{Fitting the model}

The different models for the different dependent variables, viz. clarity, color index, betalain content and ascorbic acid, were derived as represented by the Eq. 3, Eq. 4, Eq. 5 and Eq. 6, respectively. The values of different indicators for the model fitting were obtained for these selected parameters as reported in the Table 2. The calculated F-value was significant at $p<0.001$ for all the selected responses. At the same time, all these parameters possessed non-significant lack of fit $(p>0.05)$. These values indicated that the models as derived for all the selected parameters were fitted and reliable. The $R^{2}$ and $A d j-R^{2}$ value for all the responses as determined through regression analysis were higher than the 0.8 , which demonstrated the adequacy, good fit and high significance of the model. The Pred- $R^{2}$ value for all the factors was in reasonable agreement with the Adj- $R^{2}$. The high Adeq Precision value ( $>4$ ) again supported the significance of all the derived models. The small value of coefficient of variation for all the responses explained that the experimental results were precise and reliable (Table 2).

\section{Optimization of process variables}

Among the different independent variables, enzyme concentration has the greatest impact on the processing cost. To economize the process, minimum enzyme concentrations were used as criteria in numerical optimization and ideal operational conditions were derived. Accordingly, the goals that were set for variables and responses to obtain the optimum processing condition are illustrated in the Table 3 . Under these constraints, the optimum treatment conditions were found to be, $0.036 \%$

\begin{tabular}{|c|c|c|c|c|}
\hline Source & $\begin{array}{c}\text { Clarity } \\
(\% \mathrm{~T})\end{array}$ & $\begin{array}{l}\text { Color index } \\
\qquad(a b s)\end{array}$ & $\begin{array}{l}\text { Betalain content } \\
\text { (mg/L of juice) }\end{array}$ & $\begin{array}{c}\text { Ascorbic acid } \\
(\mathrm{mg} / 100 \mathrm{~g})\end{array}$ \\
\hline Model & $49.51^{\star \star \star}$ & $0.593^{* *}$ & $542.63^{* * *}$ & $9.223^{* * *}$ \\
\hline \multicolumn{5}{|l|}{ Linear terms } \\
\hline$b_{1}\left(X_{1}\right)$ & 0.285 & $-0.009^{\star}$ & 0.69 & -0.008 \\
\hline$b_{2}\left(X_{2}\right)$ & $-1.968^{\star \star \star}$ & $-0.034^{* \star *}$ & $-8.24^{\star \star \star}$ & $-0.187^{\star \star \star}$ \\
\hline$b_{3}\left(X_{3}\right)$ & $1.983^{\star \star \star}$ & $0.008^{*}$ & $3.53^{\star \star \star}$ & $-0.152^{\star \star \star}$ \\
\hline \multicolumn{5}{|l|}{ Interaction terms } \\
\hline$b_{12}\left(X_{1} X_{2}\right)$ & $-1.806^{\star \star \star}$ & -0.005 & 1.50 & -0.018 \\
\hline$b_{13}\left(X_{1} X_{3}\right)$ & 0.271 & -0.008 & 0.41 & $0.135^{\star \star \star}$ \\
\hline$b_{23}\left(X_{2} X_{3}\right)$ & 0.111 & 0.002 & $5.03^{* * *}$ & -0.018 \\
\hline \multicolumn{5}{|l|}{ Quadratic terms } \\
\hline $\mathrm{b}_{11}\left(\mathrm{X}_{1}^{2}\right)$ & $-0.787^{* *}$ & $-0.016^{\star \star \star}$ & $-5.36^{* * *}$ & -0.016 \\
\hline$b_{22}\left(X_{2}^{2}\right)$ & $-1.975^{\star \star \star}$ & $-0.016^{\star \star *}$ & $-7.84^{\star * \star}$ & $-0.074^{* *}$ \\
\hline$b_{33}\left(X_{3}^{2}\right)$ & $0.641^{*}$ & $-0.017^{\star \star \star}$ & $-2.96^{\star *}$ & $-0.069^{\star \star}$ \\
\hline \multicolumn{5}{|c|}{ Indicators for model fitting } \\
\hline $\mathrm{R}^{2}$ & 0.963 & 0.965 & 0.971 & 0.961 \\
\hline $\operatorname{Adj}-R^{2}$ & 0.929 & 0.934 & 0.945 & 0.925 \\
\hline Pred- $\mathrm{R}^{2}$ & 0.815 & 0.793 & 0.821 & 0.740 \\
\hline Adeq. Precision & 22.11 & 16.21 & 18.51 & 19.42 \\
\hline F-value & 28.56 & 30.71 & 37.57 & 27.15 \\
\hline Lack of Fit & NS & NS & NS & NS \\
\hline C.V., \% & 1.87 & 1.79 & 0.52 & 0.73 \\
\hline
\end{tabular}
$(w / w)$ enzyme concentration, $46^{\circ} \mathrm{C}$ incubation temperature and 112 min incubation time. The analysis showed that at

Table 2: ANOVA table for different quality characteristics of clarified prickly pear juice.

$\mathrm{X}_{1}=$ Enzyme concentration, $\mathrm{X}_{2}=$ incubation temperature, $\mathrm{X}_{3}=$ Incubation time.

***Significant at $p<0.001$, "Significant at $p<0.01$, "Significant at $p<0.05$. 

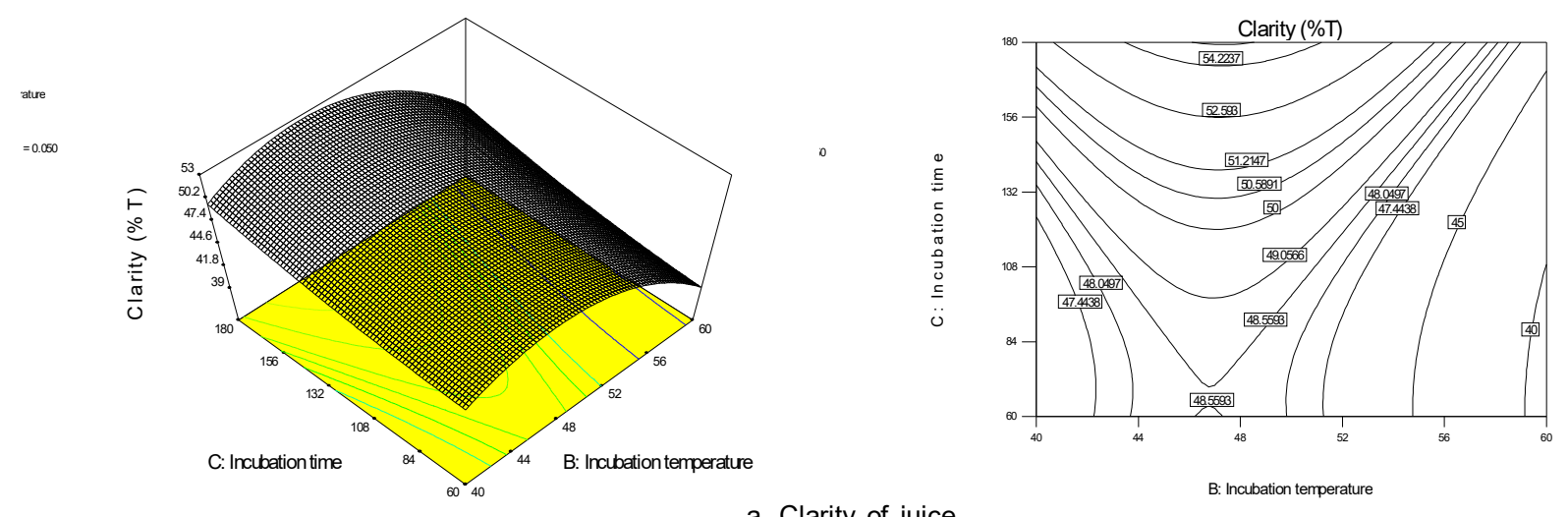

a. Clarity of juice
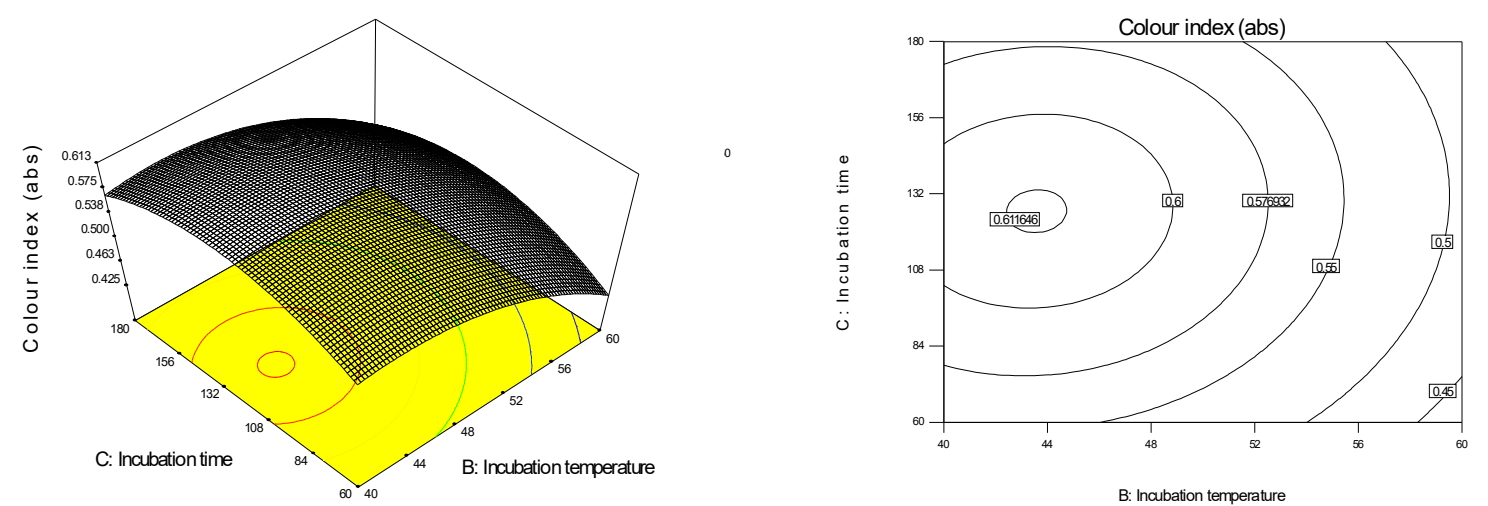

b. Color index of juice
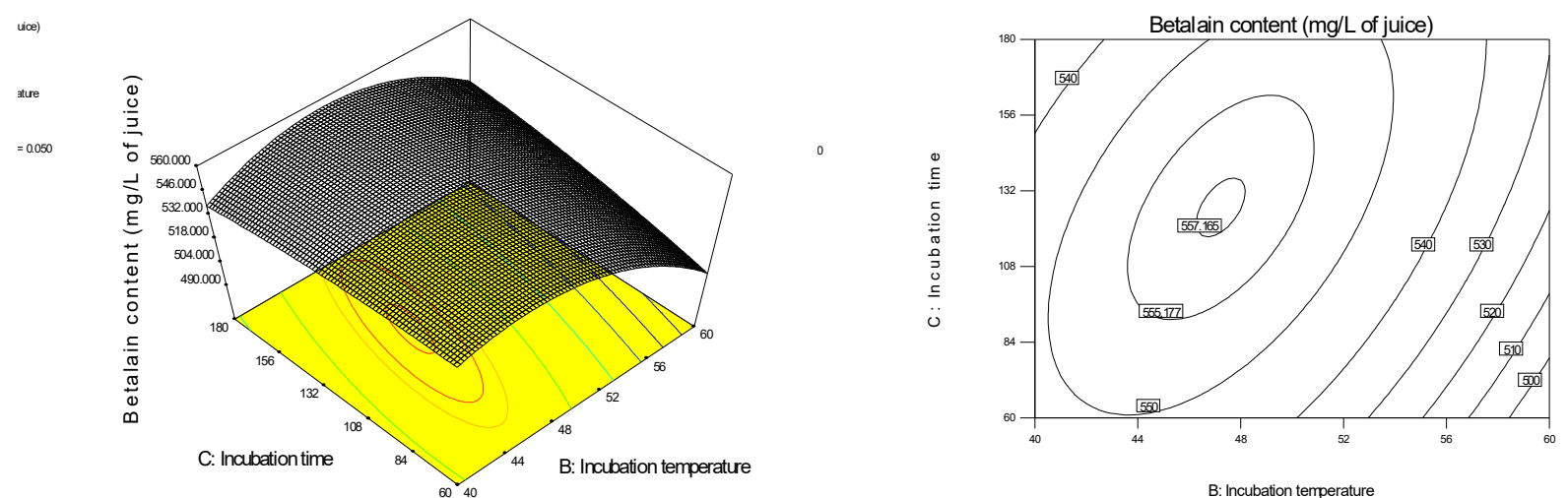

c. Betalain content of juice
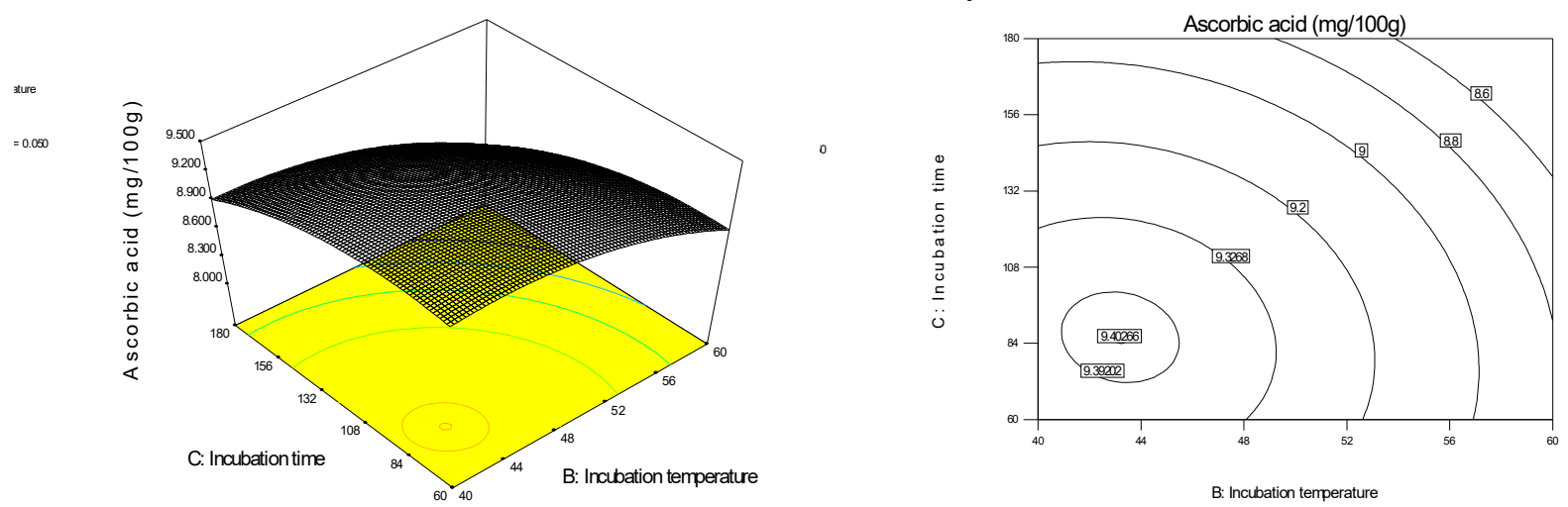

d. Ascorbic acid content of juice

Fig 2: Interaction effect of incubation temperature and incubation time on clarity, color index, betalain content and ascorbic acid (Enzyme concentration was at the centre point, i.e. $0.05 \%$ ). 
Optimization of Prickly Pear Juice Clarification for Better Retention of Betalain and Color Properties
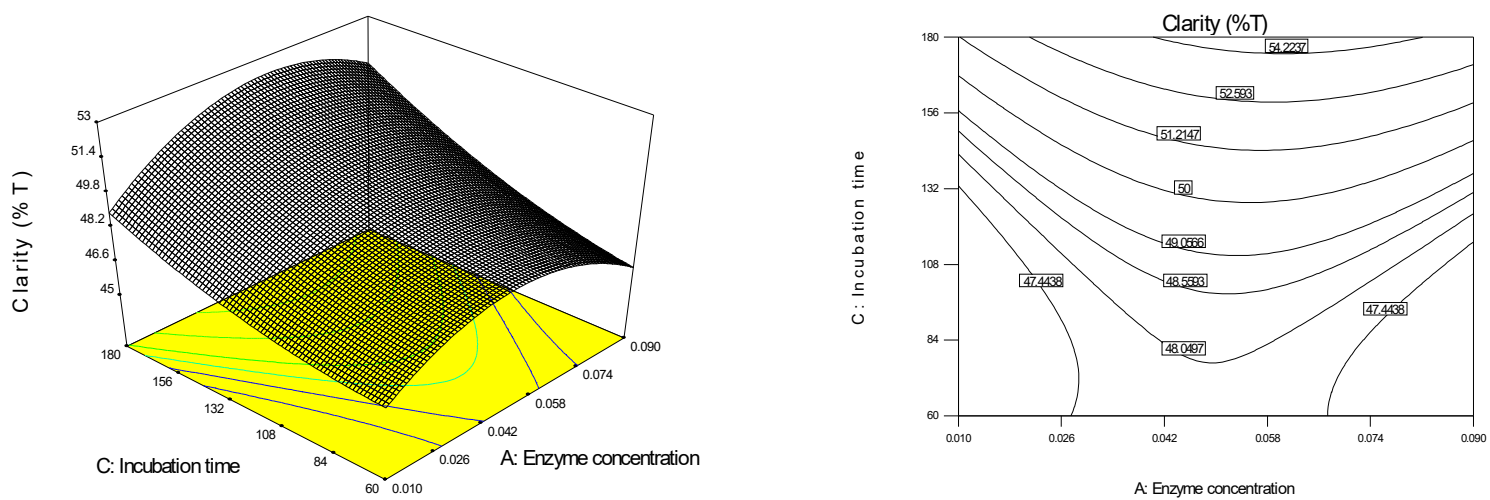

a. Clarity of juice
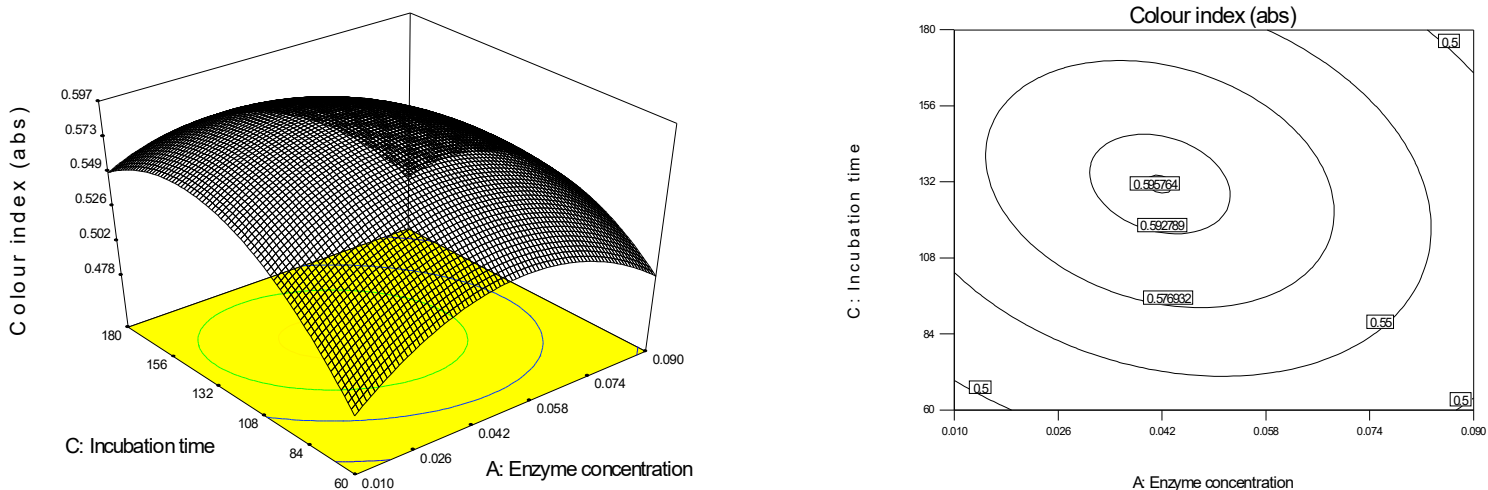

b. Color index of juice
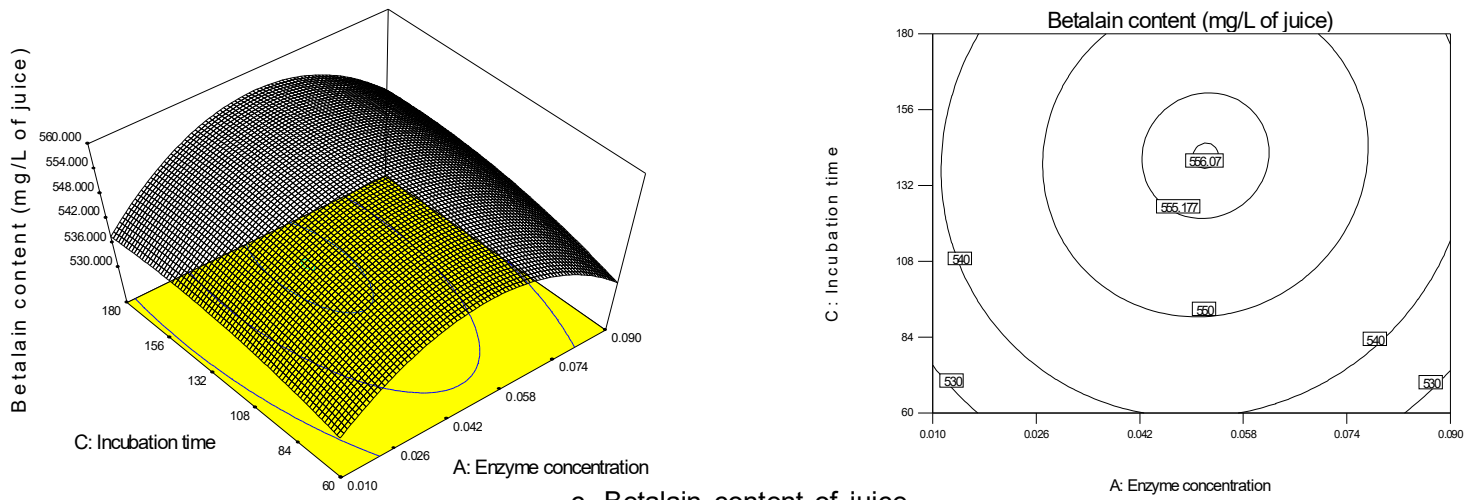

c. Betalain content of juice
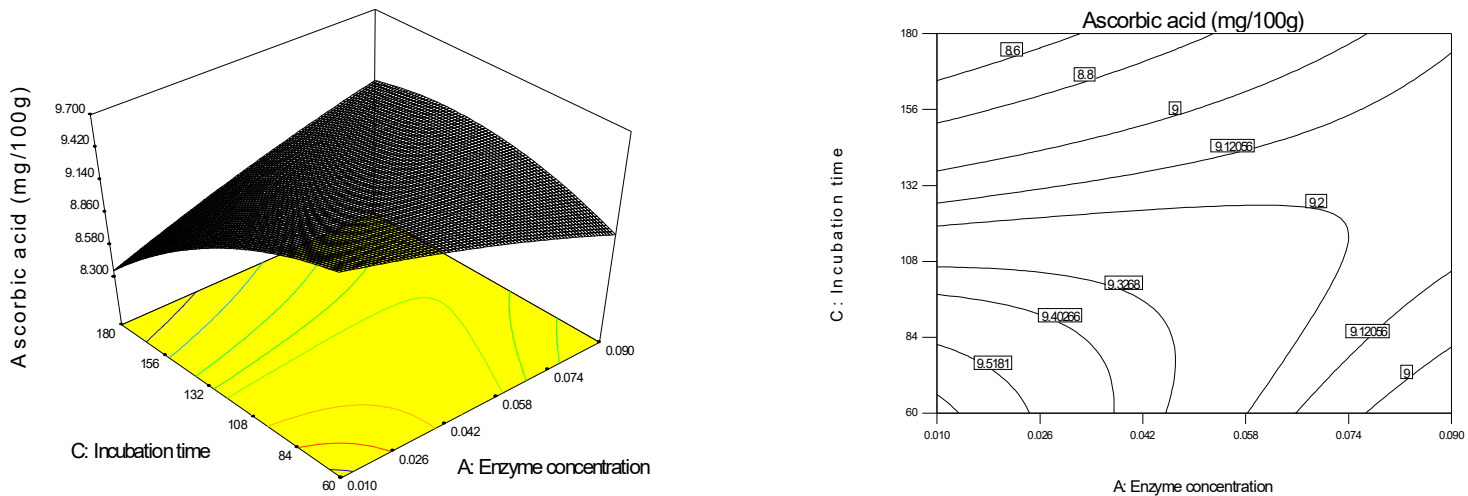

d. Ascorbic acid content of juice

Fig 3: Interaction effect of enzyme concentration and incubation time on clarity, color index, betalain content and ascorbic acid (Incubation temperature was at the centre point, i.e. $50^{\circ} \mathrm{C}$ ). 
Optimization of Prickly Pear Juice Clarification for Better Retention of Betalain and Color Properties

Table 3: Numerical optimization of prickly pear juice clarification.

\begin{tabular}{lcc}
\hline & Variables & Optimum value \\
\hline Constraint & Goal & 0.036 \\
\hline Enzyme concentration $(\%)$ & Minimize & $46.4(46)$ \\
Incubation temperature $\left({ }^{\circ} \mathrm{C}\right)$ & In the range & $112.4(112)$
\end{tabular}

Responses

\begin{tabular}{lcccc}
\hline Constraint & Goal & Predicted value & Experimental value & Deviation $(\%)$ \\
\hline Clarity $(\% \mathrm{~T})$ & Maximize & 48.59 & 47.86 & 1.50 \\
Color index $(\mathrm{abs})$ & Maximize & 0.603 & 0.598 & 0.83 \\
Betalain content $(\mathrm{mg} / \mathrm{L}$ of juice) & Maximize & 542.93 & 536.54 & 1.18 \\
Ascorbic acid $(\mathrm{mg} / 100 \mathrm{~g})$ & Maximize & 9.346 & 9.14 & 2.20 \\
Desirability & - & 0.780 & - & - \\
\hline
\end{tabular}

this combination of enzyme concentration, incubation temperature and incubation time, it would be possible to produce the juice with a clarity of $48.59 \% \mathrm{~T}$, color index of $0.603 \mathrm{abs}$, betalain content of $542.93 \mathrm{mg} / \mathrm{L}$ of juice and ascorbic acid of $9.35 \mathrm{mg} / 100 \mathrm{~g}$. Using these optimized conditions, the experiments were again conducted to find the variation in the different response variables. The results revealed that the experimental values of conducted experiments were very close to the predicted values (Table 3 ). This implied that there was a high degree of fit between the observed and predicted values from the regression models and each model was quite accurate in prediction. The closeness of the observed and predicted responses indicated the validity of developed model.

\section{CONCLUSION}

The commercial pectinase enzyme presented an excellent result for improving the clarity of prickly pear juice with better retention of other quality parameters. The different process conditions for enzymatic treatment revealed that all these selected variables noticeably affected the clarity, color index, betalain content and ascorbic acid content of the prickly pear juice. The second order polynomial equations adequately described the relations between the processing and response variables. The response surface and contour plots assisted to study the interaction effect of process variables on response variables as well as to obtain the optimum levels for enzymatic pretreatments. The optimum condition for clarification of prickly pear juice could be recommended as: enzyme concentration of $0.036 \%$, incubation temperature of $46{ }^{\circ} \mathrm{C}$ and incubation time of $112 \mathrm{~min}$. The obtained result would be beneficial for juice industry to improve the clarity and color index along with preservation of betalain content and ascorbic acid of the prickly pear fruit juice.

\section{REFERENCES}

Balasubramanian, S., Shukla, V. and Singh, R. (2020). Optimization of process parameters for soaked soybean splits roasting using response surface methodology. Asian Journal of Dairy and Food Research. 39(4): 308-316. DOI: 10.18805 lajdfr.DR-1541.
Cai, Y.Z. and Corke, H. (1999). Amaranthus betacyanin pigments applied in model food systems. Journal of Food Science. 64: 869-873.https://doi.org/10.1111/j.1365-2621.1999.tb 15930.x.

Davara, P.R., Varshney, A.K., Naliapara, V.A. and Sangani, V.P. (2017). Response surface modeling of prickly pear juice clarification. Advances in Food Science and Engineering. 1(2): 80-92.

Demir, N., Acar, J., Sarýoðlu, K. and Mutlu, M. (2001). The use of commercial pectinase in fruit juice industry. Part 3: Immobilized pectinase for mash treatment, Journal of Food Engineering. 47: 275-280. https://doi.org/10.1016/S0260-8774 (00) 00127-8

Fernandez-López, J.A. and Luis-Almela, L. (2001). Application of high-performance liquid chromatography to the characterization of the betalain pigments in cactus pear fruits. Journal of chromatography. 913(1-2): 415-420. https://doi.org/ 10.1016/S0021-9673(00)01224-3.

Hans, Y.S.H. (1992). The guide book of food chemical experiments, Pekin Agricultural University Press, Pekin, USA.

Joshi, S., Singh, A., Laobangdisa, S.B. and Kulkarni, S. (2020). Utilization of prickly pear for preparation of fruit dessert. Asian Journal of Dairy and Food Research. 39(1): 58-65. DOI: 10.18805/ajdfr.DR-1476.

Karangwa, E., Khizar, H., Rao, L., Nshimiyimana, D.S., Foh, M.B.K., Li, L., Xia, S.Q. and Zhang, X.M. (2010). Optimization of processing parameters for clarification of blended carrotorange juice and improvement of its carotene content. Advance Journal of Food Science and Technology. 2(5): 268-278.

Kaur, R., Singh, P.K., Talwar, G. and Anurag (2018). Studies on sensory and textural properties of milk cake using response surface methodology. Asian Journal of Dairy and Food Research. 37(3): 167-174. DOI: 10.18805/ajdfr.DR-1316.

Kgatla, T.E., Howard, S.S. and Hiss, D.C. (2011) Colour stability of wild cactus pear juice. World Academy of Science, Engineering and Technology. 56: 249-254. https://doi.org/ 10.5281/zenodo. 1080476 .

Khuri, A.I. and Cornell, J.A. (1987). Response surface design and analysis. Marcel Dekker, Inc., New York.

Lee, W.C., Yusof, S., Hamid, N.S.A. and Baharin, B.S. (2006). Optimizing conditions for enzymatic clarification of banana juice using response surface methodology (RSM). Journal of Food Engineering. 73(1): 55-63. https://doi.org/10.1016 /j.jfoodeng.2005.01.005. 
Mackay, G., Brown, J. and Torrence, C. (1990). The processing potential of tubers of the cultivated potato, Solanum tuberosum L. after storage at low temperatures. Potato Research. 33: 211-218. https://doi.org/10.1007/BF02358448. Meydov, S., Saguy, I. and Kopelman, I. (1977). Browning determination in citrus products. Journal of Agricultural and Food Chemistry. 25(3): 602-604. https://doi.org/10.1021/jf60211a030.

Moreno-Álvarez, M.J., Medina, C., Antón, L., García, D. and BelénCamacho, D. (2003). Uso de pulpa de tuna (Opuntia boldinghii) en la elaboración de bebidas cítricas pigmentadas. Interciencia. 28(9): 539-543.

Nilsson, T. (1970). Studies into the pigments in beetroot (Beta vulgaris L. ssp. vulgaris var. rubra L.). Lantbrukhogskolans Annaler. 36: $179-219$

Prema, R.S., Abirami, A., Nandhini, R. and Ravi Kumar, G. (2018). Optimization of ingredients composition of non-wheat pasta based on cooking quality using response surface methodology (RSM). Asian Journal of Dairy and Food Research. 37(3): 227-231. DOI: 10.18805/ajdfr.DR-1331.
Sáenz, C. and Sepúlveda, E. (2001) Cactus pear juices. Journal of the Professional Association for Cactus Development. 4: 3-10.

Saxena, D., Sabikhi, L., Chakraborty, S.K. and Singh, D. (2014). Process optimization for enzyme aided clarification of watermelon juice. Journal of Food Science and Technology. 51(10): 2490-2498. https://doi.org/10.1007/s13197-0120720-1.

Seidl, R., Peyrl, A., Nicham, R. and Hauser, E. (2000). A taurine and caffeine-containing drink stimulates cognitive performance and well-being. Amino Acids. 19: 635-642. https://doi.org/ 10.1007/s007260070013.

Sin, H.N., Yusof, S., Hamid, N.S.A. and Rahman, R.A. (2006). Optimization of enzymatic clarification of sapodilla juice using response surface methodology. Journal of Food Engineering. 73: 313-319. https://doi.org/10.1016/j.jfood eng.2005.01.031. 